\title{
KOMUNIKASI MULTIKULTURAL DI MEDIA TELEVISI INDONESIA: KONTROL PEMERINTAH ATAS IMPERIALISME BUDAYA
}

\section{MULTICULTURAL COMMUNICATION IN INDONESIA TELEVISION: GOVERNMENT CONTROL ON CULTURAL IMPERIALISM}

\author{
Muntadliroh \\ Humas Balai Konservasi Tumbuhan Kebun Raya Eka Karya Bali LIPI \\ Candikuning, Baturiti, Tabanan, Bali, 82191 \\ email : mun_tadliroh@yahoo.com
}

(Diterima: 24-01-2018; Direvisi: 07-05-2018; Disetujui terbit: 07-06-2018)

\begin{abstract}
Abstrak
Tulisan ini bertujuan untuk mendeskripsikan implementasi Undang-Undang Penyiaran sebagai salah satu bentuk kebijakan komunikasi multikultural di televisi Indonesia. Ini adalah upaya pemerintah Indonesia untuk mengendalikan imperialisme budaya asing. Melalui Undang-Undang Penyiaran, Pemerintah berusaha untuk melindungi budaya Indonesia dan mendorong munculnya nilai-nilai multikultural di televisi Indonesia. Namun, saat ini budaya lokal di televisi Indonesia menghadapi ancaman hegemoni dan invasi budaya asing. Fenomena ini relevan dengan Teori Imperialisme Budaya dimana media Barat telah mendominasi dunia. Fakta dalam pelaksanaannya, Undang-Undang Penyiaran Indonesia menghadapi tantangan kapitalisme media dan imperialisme budaya. Oleh karena itu, Komisi Penyiaran Indonesia dan masyarakat perlu bekerja sama dalam menjaga nilai multikulturalisme Indonesia melalui media televisi agar tidak terkikis oleh budaya asing.

Kata kunci: Komunikasi Multikultural, Undang-Undang Penyiaran, Televisi, Imperialisme Budaya.
\end{abstract}

\begin{abstract}
This paper aims to describe the implementation of the Broadcasting Act as a policy of multicultural communication in Indonesian television. This is the government's attempt to control foreign cultural imperialism. Through the Broadcasting Act, the Government of Indonesia seeks to protect Indonesian culture and encourage the emergence of multicultural values on Indonesian television. But now local culture on Indonesian television face the hegemony and invasion of foreign cultures. This is relevant with Cultural Imperialism Theory that Western media has dominated the world. In fact, the Indonesian Broadcasting Act faces media capitalism and cultural imperialism. Therefore, the Indonesian Broadcasting Commission and the public need to work together to maintain the value of Indonesian multiculturalism not to be displaced by foreign cultures.
\end{abstract}

Keywords: Multicultural Communication, Broadcasting Act, Television, Cultural Imperialism. 


\section{PENDAHULUAN}

Bhineka Tunggal Ika adalah simbol multikulturalisme dalam masyarakat Indonesia yang merepresentasikan keberagaman suku, adat, ras, agama, dan budaya yang ada di Indonesia dari Sabang hingga Merauke. Data Badan Pusat Statistik (2016) mencatat jumlah penduduk Indonesia mencapai 257.912.349 jiwa dengan luas wilayah $1.919 .440 \mathrm{~km} 2$, memiliki 17.504 pulau dengan sekitar 6000 pulau saja yang berpenghuni, dan mempunyai bahasa daerah sebanyak 742 bahasa. Kedinamisan ini menjadi potensi utama komunikasi multikultural di Indonesia. Kajian komunikasi multukultural tidak dapat dipisahkan dengan aspek sosio budaya. Di dalam komunikasi multikultural melekat sistem kepercayaan, nilai, norma sosial budaya yang berkembang di masyarakat. Dalam konteks ini, komunikasi multikultural memainkan peran vital dalam proses akulturasi, asimilasi, dan adaptasi budaya lokal dengan budaya baru.

Komunikasi multikultural memfokuskan pada bagaimana sistem kepercayaan, norma, nilai sosial kultural yang berkembang di suatu wilayah mempengaruhi pola komunikasi masyarakat; pesan komunikasi interpersonal dalam interaksi simbolis multikultural lewat representasi produksi budaya maupun reproduksi budaya; pesan multikultural media massa global maupun lokal berpengaruh pada simbol-simbol yang digunakan masyarakat sebagai alat untuk berkomunikasi; sejauh mana transformasi budaya masyarakat multkultural memberi sumbangan terhadap integrasi nasional, solidaritas sosial; sejauh mana ketidakadilan, kesenjangan, hegemoni, dominasi, ketidaksetaraan mampu menjadi sumber konflik budaya (Purwasito, 2015). Dalam praktiknya, perwujudan komunikasi multikultural tersebut salah satunya dapat berupa tayangan yang direpresentasikan di media massa, termasuk televisi.

Dalam konteks ini, televisi memiliki andil dalam membingkai komunikasi multikultural melalui tayangan yang disajikan kepada khalayak. Hal ini tidak terlepas dari fungsi media massa termasuk televisi yaitu menyediakan informasi mengenai kondisi lingkungan dalam arti menjadi alat untuk mengawasi lingkungan (surveillance of the environment), menghubungkan bagian-bagian dalam masyarakat (correlation of the part of society), mengirimkan warisan sosial (transmission of social heritage), dan memberikan hiburan (to entertainment), Laswell dalam Littlejohn (2005). Di Indonesia, momentum pasca jatuhnya Rezim Orde Baru telah membawa televisi bergeser kepada tatanan yang lebih liberal dan mengedepankan fungsi hiburan. Pergeseran ideologi pertelevisian di Indonesia ini tidak terlepas dari tatanan sosial politik di Era Reformasi yang menempatkan media dalam kebebasan pers dan hilangnya belenggu kreativitas, serta kebijakan desentralisasi dalam pemerintahan yang memudahkan lahirnya televisi daerah (Sutanto et al, 2010).

Menengok tayangan televisi Indonesia saat ini, hiburan adalah salah satu program yang paling banyak diminati dan ditonton oleh penonton televisi Indonesia (Sutanto et al, 2010). Data UC News mencatat jumlah pemirsa televisi mencakup 99,8\% dari total populasi dengan durasi rata-rata 1.782,5 menit setiap minggu (selular.id, 2017). Tidak dapat dipungkiri bahwa televisi adalah media yang paling besar peluangnya menayangkan hiburan dalam 
bentuk yang beragam. Acara hiburan seperti sinetron, film, infotainment, dan reality show masih mendominasi televisi Indonesia. Tidak jarang, konten tayangan hiburan televisi tersebut mengandung unsur multikulturalisme, misalnya: komedi Keluarga Minus, Suami-suami Takut Istri, serial anak Adit-Sopo-Jarwo, Jejak Petualang yang mengeksplorasi kehidupan suku-suku di pedalaman Indonesia, ajang pencarian bakat yang menampilkan peserta dari berbagai daerah di Indonesia. Tidak mengherankan bila saluran televisi yang menayangkan hiburan tersebut menjadi idola pemirsa. Hasil survei Litbang Kompas (2016) terhadap masyarakat Jakarta menunjukkan dua dari lima responden memilih RCTI, SCTV, dan Indosiar sebagai stasiun televisi yang ditonton setiap hari. Tayangan hiburan berkonten multikulturalisme tersebut umumnya tayang di stasiun televisi yang menjadi favorit pemirsa.

Disadari ataupun tidak, tayangan hiburan lokal yang memuat konten multikulturalisme Indonesia sedang menghadapi ancaman berupa hadirnya program acara asing yang turut tayang di chanel hiburan televisi Indonesia. Beberapa program asing yang tayang di televisi Indonesia diantaranya: Anandhi (ANTV), Mohabbatein (ANTV), Bioskop Trans TV (Trans TV), Upin \& Ipin (MNC TV), dan Naruto (Global TV). Tayangantayangan tersebut masuk dalam nominasi tayangan asing terpopuler dalam ajang Indonesian Television Awards 2017 (rappler.com, 2017). Bagaimanapun, kita tidak boleh abai pada dampak yang ditimbulkan oleh tayangan televisi. Jangan sampai invasi tayangan asing menjadi dominan dan mengalahkan konten lokal.

Permasalahan munculnya invasi budaya asing ini penting untuk dielaborasi mengingat adanya sisi negatif dari imperialisme budaya yang dikhawatirkan dapat mendegradasi tayangan lokal yang mengandung unsur multikulturalisme di televisi Indonesia jika hal tersebut tidak dikendalikan. Imperialisme budaya semacam ini dapat membawa dampak yang sangat berbahaya karena sangat mudah masuk ke dalam suatu negara, khususnya nengara dunia ketiga seperti Indonesia. Ketika suatu negara sudah terkena dampak imperialisme, maka negara tersebut akan kesulitan untuk melepaskan diri. Dalam konteks ini, media turut berperan menyebarkan konten budaya asing yang menginvasi suatu negara dalam posisi yang dilematis. Di satu sisi, media mempunyai peran positif membantu membuka wawasan khalayak mengenai perkembangan informasi global terbaru. Di sisi lain, media memperkenalkan nilai-nilai budaya asing yang dapat mengikis nilai-nilai tradisional yang akan menghilangkan keaslian budaya lokal (Sutanto et al, 2010).

Untuk mengatur proporsi tayangan berbudaya asing dan tayangan lokal di televisi Indonesia, pemerintah berupaya melakukan fungsi kontrol melalui kebijakan komunikasi multikulturalisme di media penyiaran Indonesia. UU Pokok Pers no 40/1999 dan UU Penyiaran no $32 / 2002$, UU Penyiaran no 32/2002, PP Nomor 50 Tahun 2005 tentang Penyelenggaraan Penyiaran Lembaga Penyiaran Swasta, serta Peraturan KPI tentang SPS adalah kebijakan formal yang dikeluarkan oleh Pemerintah Indonesia dalam upaya meminimalisir terjadinya imperialisme budaya yang mengalahkan konten budaya lokal Indonesia. Pokok pikiran umum dari kebijakan tersebut dalam kaitannya dengan komunikasi multikultural Indonesia adalah mengatur 
konten lokal yang wajib mengedepankan unsur sosial budaya, serta tetap memprioritaskan dominasi konten lokal dalam tayangan televisi Indonesia. Berpijak dari fakta di atas, tulisan ini bertujuan mendeskripsikan implementasi komunikasi multikulturalisme dalam tayangan televisi di Indonesia dilihat dari aspek implementasi kebijakan pemerintah Indonesia dalam upaya mengontrol imperialisme budaya asing, serta problematika kualitas konten tayangan lokal dan asing yang tayang di televisi Indonesia.

\section{Cultural Imperialism Theory dan Relevansinya Terhadap Isu Terkini}

Cultural Imperialism Theory pertama kali digagas oleh Herb Schiller di tahun 1973. Perspektif teori ini menjelaskan bahwa media massa negara Barat mendominasi media di seluruh dunia (Nurudin, 2007). Hal ini terjadi karena media Barat mempunyai efek yang kuat dalam mempengaruhi media di negara berkembang, media Barat memiliki sumber daya dan teknologi maju yang memungkinkan konten-konten media diproduksi dengan kualitas yang lebih baik. Herbert Schiller dalam karyanya yang berjudul "Komunikasi dan Budaya Dominasi" mengusulkan penggunaan istilah imperialisme budaya untuk menggambarkan dan menjelaskan cara di mana perusahaan multinasional besar, termasuk media di negara-negara maju mendominasi negara-negara berkembang (Sutanto et al, 2010). Disamping itu, imperialisme budaya mengacu pada dugaan dominasi global komoditas hiburan dan budaya Amerika, tetap menjadi kerangka acuan untuk istilah ini (Dunch, 2002).
Dengan kata lain, imperialisme budaya dalam lingkup ini merupakan praktek untuk mempromosikan, membedakan, memisahkan, atau penyuntikan budaya dari satu masyarakat ke dalam yang lain. Ini seperti sebuah metafora kolonialisme yang menggunakan produk budaya dunia pertama untuk menyerang dan menaklukkan budaya lokal negara dunia ketiga. Hingga saat ini, imperialisme budaya telah menjadi paradigma dominan untuk mengkonseptualisasikan, pelabelan, memprediksi, dan menjelaskan pengaruh televisi internasional dari dakwaan dan pendekatan yang diambil dalam hidup dan bermanfaat (Sutanto et al, 2010).

Lebih jauh, yang perlu diperhatikan dari adanya imperialisme budaya ini adalah dampak yang ditimbulkannya. Dalam Cultural Imperialism Theory dinyatakan bahwa media massa mampu mengubah pola yang sudah ada dalam kelompok tertentu. Akibatnya, ada efek peniruan yang akan berlanjut kepada masyarakat. Ketika khalayak setiap hari menonton televisi atau media lainnya yang berisi pandangan-pandangan budaya yang dilahirkan oleh budaya Barat, maka lambat laun mereka akan terpengaruh. Ketika terjadi proses imitasi (peniruan) dari negara berkembang, saat itu juga akan terjadi kehancuran budaya asli negara berkembang. Meskipun Cultural Imperialism Theory telah dicetuskan sekitar 44 tahun lalu, namun teori ini masih relevan dengan isu perkembangan imperialisme budaya yang terjadi saat ini khususnya invasi tayangan asing di media televisi Indonesia. Hal ini menarik untuk dikaji lebih lanjut terutama dalam kaitannya dengan implementasi kebijakan komunikasi multikultural di televisi Indonesia. 


\section{PEMBAHASAN}

\section{Kebijakan Komunikasi Multikultural dalam Media Penyiaran Indonesia}

Purwasito (2015) menganggap bahwa perkembangan teknologi informasi dan komunikasi menyebabkan terjadi transformasi multikultural yang terkait dengan media global. Pengetahuan masyarakat menjadi lebih luas dengan adanya pemaparan tentang banyaknya perbedaan simbol-simbol dan pesan-pesan yang dihadirkan oleh teknologi. Setiap media mempunyai point of view sendiri dengan menggunakan sifat media framing yang merupakan pola spesifik dari pemberitaan pada tiap-tiap media yang menonjolkan pada aspek-aspek tertentu (Lecheler, Bos, \& Vliegenthart, 2015). Hal tersebut akhirnya membentuk persepsi yang berbeda pada masyarakat, kadang beberapa kelompok tertentu sengaja membuat pemberitaan di media untuk mempromosikan budaya, ras ataupun nilainilai yang mereka anut agar dapat menggiring massa atau sebagai cara agar beberapa kelompok lain memahami cara pandang mereka.

Di Indonesia, multikulturalisme dalam media penyiaran telah diatur secara formal oleh pemerintah melalui:

1. UU Pokok Pers no 40/1999 dan UU Penyiaran no 32/2002 sudah menstimuli sosialisasi multikultural. Dalam UU Pokok Pers no 40/1999: pasal 5: “... memberitakan peristiwa dan opini dengan menghormati norma agama dan rasa kesusilaan masyarakat; Pasal 6: "menegakkan nilai dasar demokrasi, mendorong supremasi hukum dan HAM serta menghormati kebhinekaan.

2. UU Penyiaran no 32/2002: Pasal (2): "Penyiaran

diselenggarakan berdasarkan Pancasila dan UndangUndang Dasar Negara Republik Indonesia Tahun 1945 dengan asas manfaat, adil dan merata, kepastian hukum, keamanan, keberagaman, kemitraan, etika, kemandirian, kebebasan, dan tanggung jawab; Pasal 3: Penyiaran diselenggarakan dengan tujuan untuk memperkukuh integrasi nasional, terbinanya watak dan jati diri bangsa yang beriman dan bertakwa, mencerdaskan kehidupan bangsa, memajukan kesejahteraan umum, dalam rangka membangun masyarakat yang mandiri, demokratis, adil dan sejahtera, serta menumbuhkan industri penyiaran Indonesia; Pasal (36) tentang isi siaran, antara lain: Isi siaran wajib dijaga netralitasnya dan tidak boleh mengutamakan kepentingan golongan tertentu, Isi siaran dilarang bersifat fitnah, menghasut, menyesatkan dan/atau bohong; menonjolkan unsur kekerasan, cabul, perjudian, penyalahgunaan narkotika dan obat terlarang; atau mempertentangkan suku, agama, ras, dan antar golongan; dilarang memperolokkan, merendahkan, melecehkan dan/atau mengabaikan nilai-nilai agama, martabat manusia Indonesia, atau merusak hubungan internasional.

3. PP Nomor 50 Tahun 2005 tentang Penyelenggaraan Penyiaran Lembaga Penyiaran Swasta Pasal 14 ayat (1) Isi siaran wajib mengandung informasi, pendidikan, hiburan, dan manfaat untuk pembentukan intelektualitas, watak, moral, kemajuan, kekuatan bangsa, menjaga persatuan dan kesatuan, serta mengamalkan nilainilai agama dan budaya Indonesia; dan ayat (2) Isi siaran jasa penyiaran 
televisi, yang diselenggarakan oleh Lembaga Penyiaran Swasta wajib memuat sekurang-kurangnya $60 \%$ (enam puluh perseratus) mata acara yang berasal dari dalam negeri dari seluruh jumlah waktu siaran setiap hari.

4. Peraturan KPI tentang SPS Pasal 68: (1) Program siaran lokal wajib diproduksi dan ditayangkan dengan durasi paling sedikit $10 \%$ (sepuluh per seratus) untuk televisi dan paling sedikit $60 \%$ (enam puluh per seratus) untuk radio dari seluruh waktu siaran berjaringan per hari. (2) Program siaran lokal sebagaimana yang dimaksud pada ayat (1) di atas paling sedikit $30 \%$ (tiga puluh per seratus) di antaranya wajib ditayangkan pada waktu prime time waktu setempat. (3) Program siaran lokal sebagaimana yang dimaksud pada ayat (1) secara bertahap wajib ditingkatkan hingga paling sedikit 50\% (lima puluh perseratus) untuk televisi dari seluruh waktu siaran berjaringan per hari. Norma hukum tersebut sudah sangat jelas dan tegas mengatur pada saat televisi memperoleh izin siaran di wilayah setempat dan memulai siaran wajib dengan program lokal sebesar $10 \%$ dari total waktu siarannya. KPI juga mewajibkan $30 \%$ dari total durasi siaran lokal harus disiarkan di prime time. Tidak hanya itu angka durasi siaran lokal juga harus bertambah sampai dengan minimal 50\%.

Pasal-pasal tersebut di atas merupakan bagian dari kebijakan penyiaran di Indonesia yang menunjukkan bahwa konten siaran yang mengandung unsur multikulturalisme Indonesia menjadi prioritas bersama. Oleh sebab itu, secara umum tujuan dirumuskannya kebijakan penyiaran di Indonesia adalah menjamin dan melindungi kebebasan berekspresi atau mengeluarkan pendapat secara lisan dan tertulis, termasuk menjamin kebebasan berkreasi dengan betumpu pada asas keadilan, demokrasi, dan supremasi hukum. Serta pengembangan penyiaran pada prinsipnya diarahkan pada terciptanya siaran yang berkualitas, bermartabat, mampu menyerap, dan mereflesikan aspirasi masyarakat yang beraneka ragam, untuk meningkatkan daya tangkal masyarakat terhadap pengaruh buruk nilai budaya asing. Dengan kata lain, kebijakan penyiaran ini adalah bentuk kontrol pemerintah terhadap penyelenggaraan penyiaran di Indonesia berdasarkan asas kebhinekaan Indonesia. Meskipun dalam prakteknya, seringkali pemerintah dalam konteks ini diwakili Komisi Penyiaran Indonesia berhadapan dengan kepentingan masyarakat yang beragam.

\section{Menakar Kualitas Konten Multikulturalisme Tayangan Lokal di Televisi Indonesia vs Invasi Tayangan Berbudaya Asing}

Meskipun perkembangan media baru saat ini telah mengglobal, namun masa televisi sebagai "kotak ajaib" masih belum mati khususnya bagi masyarakat Indonesia. Penyiaran televisi menurut Undang-undang Republik Indonesia Nomor 32 Tahun 2002 tentang Penyiaran pasal 1 ayat (4) adalah media komunikasi massa dengar pandang, yang menyalurkan gagasan dan informasi dalam bentuk suara dan gambar secara umum, baik terbuka maupun tertutup, berupa program yang teratur dan berkesinambungan. Dengan demikian, televisi merupakan media penyiaran yang dapat menayangkan suara (audio) dan gambar bergerak (visual) 
sekaligus. Televisi memiliki kemampuan memvisualisasikan kata-kata yang mengandung gagasan menjadi gambar, demikian juga sebaliknya. Oleh sebab itu, teknik pengoperasiannya pun lebih rumit dan memerlukan orang-orang dengan keahlian khusus (Ardianto, 2007).

Televisi bagi masyarakat Indonesia menjadi suatu kebutuhan dalam ruang publik. Data AC Nielsen menunjukkan penetrasi media televisi di Indonesia masih mendominasi dengan angka sebesar 96\% seperti yang tertera pada gambar 1 (Katadata, 2016). Hal ini menunjukkan bahwa berbagai tayangan yang hadir di layar kaca televisi Indonesia masih diminati oleh masyarakat. Sementara itu, ragam program tayangan televisi menurut Peraturan Komisi Penyiaran Indonesia Nomor 03 Tahun 2007 Tentang Standar Program Siaran pasal 1 adalah:

a. Program faktual adalah program siaran yang menyajikan fakta nonfiksi, diproduksi dengan berpegang pada prinsip jurnalistik, terutama apabila materi yang disiarkan berkaitan dengan kebijakan publik. Yang termasuk dalam program faktual adalah program berita, features, dokumentasi, program realita (reality show), konsultasi on-air, diskusi, talkshow, jajak pendapat, pidato, ceramah, editorial, kuis, perlombaan, pertandingan olahraga, dan programprogram sejenis lainnya yang bersifat nyata, terjadi tanpa rekayasa [Ayat (8) dan (9)].

b. Program non-faktual adalah program siaran yang berisi ekspresi, pengalaman situasi dan/atau kondisi individual dan/atau kelompok yang bersifat rekayasa atau imajinatif dan bersifat menghibur. Yang termasuk dalam program non faktual adalah drama yang dikemas dalam bentuk sinetron atau film, program musik, seni, dan/atau program-program sejenis lainnya yang bersifat rekayasa dan bertujuan menghibur [Ayat (10) dan (11)].

c. Program asing adalah program utuh yang diimpor dari luar negeri [Ayat (12)].

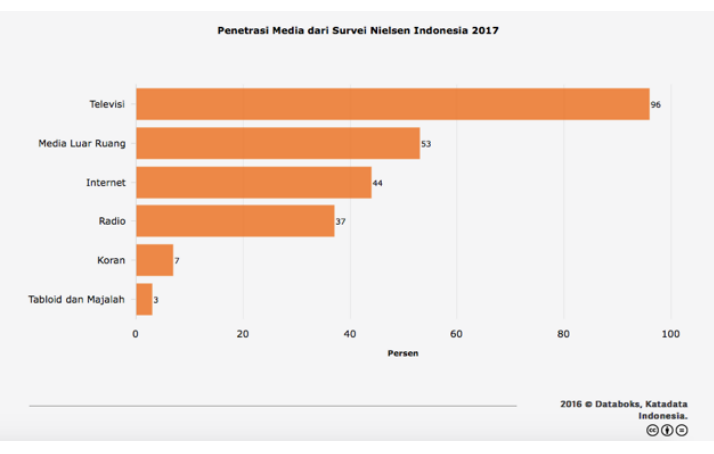

Gambar 1. Data Penetrasi Media di Indonesia tahun 2017,

Sumber: Katadata Indonesia, 2017.

Mengkaji konten multikulturalisme dalam tayangan televisi Indonesia, umumnya stasiun televisi mengembangkan kreativitasnya masing-masing dalam mengemas konten multikultural khususnya pada mata acara yang bersifat non fiksi. Beberapa program reality show yang sarat pesan multikultural diantaranya program My Trip My Adventure (Trans TV), Ethnic Runway (Trans TV), Jejak Petualang (Trans 7), Indonesia Bagus (Net TV), Bocah Petualang (Trans 7) adalah tayangan bergenre feature budaya yang mengenalkan budaya-budaya dari pelosok Indonesia, kearifan lokal dalam kehidupan sehari-hari suku-suku Indonesia. Tayangan semacam ini banyak mendapatkan apresiasi dalam KPI Awards untuk mendorong stasiun televisi lainnya agar memperbanyak produksi tayangan bernilai positif bagi masyarakat. Selain itu, apabila ada acara kebudayaan yang berskala 
nasional maupun Internasional seperti Festival Lembah Baliem, Festival Budaya Singkawang, Festival Dieng Wonosobo, Festival Sriwijaya, Jember Fashion Carnaval maka stasiun televisi tidak segan menayangkannya sebagai konten berita dalam program siarannya. Demikian halnya apabila terjadi peristiwa konflik horizontal dan vertikal dalam masyarakat Indonesia pun tetap diliput meskipun dengan bingkai yang berbeda-beda oleh stasiun televisi. Melalui tayangan-tayangan tersebut, sebetulnya televisi Indonesia telah berupaya menjalankan perannya sebagai agen multikultural yang menyebarkan konten budaya positif. Meminjam pendekatan psikoanalisis, media sebaiknya menyebarkan prinsipprinsip super-ego (internalisasi dari norma sosial, agama, budaya). Media juga membentuk semangat edukasi, mendidik masyarakat agar menjadi lebih baik; Empowerment, memberdayakan kelompok marjinal; Enlighten, memberikan pencerahan ide-ide positif, termasuk diseminasi ide multikulturalisme (Kriyantono, 2012). Hasil evalusi KPI (2016) menunjukkan indek kualitas program berita di televisi Indonesia adalah sebesar 3,49 dari skala 4, sedangkan untuk infotainment adalah sebesar 2,52 dari skala 4. Ini menunjukkan bahwa program berita dan reality show di televisi Indonesia hampir memenuhi kriteria yang diatur UU Penyiaran, termasuk dalam penyajian konten multikultur. Sedangkan infotainment masih perlu memperbaiki kontennya yang dianggap kurang menghormati kehidupan pribadi, nilai dan norma kesopanan, serta penghormatan terhadap kepentingan publik (kpi.go.id, 2016)

Disamping itu, terdapat pula konten hiburan di tayangan televisi Indonesia berupa sinetron dan film televisi yang juga sarat pesan multikultural. Istilah sinetron merupakan singkatan dari sinema elektronik yang pada dasarnya sama dengan film. Bedanya, sinetron merupakan cerita yang berlanjut atau bersambung dan diambil dengan kamera video secara elektronik (Rinawati, 2009). Sedangkan bentuk film yang dimaksud di sini adalah tayangan berupa film televisi (FTV) dimana genre ini telah diklasifikasikan oleh AC Nielsen sebagai movie drama. Contoh tayangan sinetron dan FTV yang mengandung konten multikulturalisme adalah tayangan Keluarga Minus, SuamiSuami Takut Istri, Takdir Dimas Anak Ajaib, Habibi Habibah, Gara-Gara Gino adalah beberapa tayangan yang menampilkan karakter tokoh multi etnis, multi agama, dan atribut suku tertentu dalam tayangannya. Namun, tidak jarang kritik muncul terkait konten multikulturalisme yang ditampilkan dalam drama televisi dan dinilai kebablasan. Itu sebabnya, hasil survey indeks kualitas program siaran televisi yang dilakukan oleh KPI untuk program sinetron hanya mendapatkan angka sebesar 2,52 dari skala 4 (kpi.go.id, 2016). Adapun evaluasi KPI terhadap kualitas tayangan sinetron di televisi Indonesia adalah rendahnya pembentukan watak, identitas dan jatidiri bangsa Indonesia. Dengan kata lain, unsur multikultural yang berupaya dibangun oleh karakter di dalam sinetron tersebut masih belum mencerminkan representasi positif multikulturalisme Indonesia.

Persoalan konten multikulturalisme dalam tayangan televisi Indonesia bukan hanya berkutat pada ranah kualitas saja. Saat ini tayangan lokal dihadapkan pada tantangan global berupa invasi tayangan berbudaya asing yang mendapatkan izin tayang secara resmi di televisi Indonesia 
dan diatur dalam Peraturan Komisi Penyiaran Indonesia Nomor 03 Tahun 2007 Tentang Standar Program Siaran Ayat 12. Maraknya tayangan asing di televisi Indonesia sebenarnya bukan fenomena baru. Saat televisi swasta muncul, program impor sudah menjadi sajian utama. Sen dan Hill (2001) mencatat ketika RCTI berdiri di tahun 1989, 90\% program siarannya berasal dari Amerika, SCTV memutar film-film dari China dan Hong Kong, sedangkan TPI menjadi pelopor yang membawa masuk film Bollywood. Drama asing mulai populer di Indonesia akhir tahun 1990an ketika ekspansi telenovela Amerika Latin merambah pasar Asia. Di Indonesia, RCTI dan SCTV pernah menjadi importir utama telenovela ternama seperti "Maria Mercedes", "Rosalinda", dan "Betty La Fea". Tren tayangan asing kemudian bergeser ke produk Asia Timur seperti "Meteor Garden" yang diputar di Indosiar pada tahun 2001 sekaligus menjadi tonggak popularitas drama Asia Timur. Di tahun 2002 RCTI turut memutar melodrama asal Korea, "Endless Love", yang ternyata menarik animo luar biasa. Drama Korea dengan berbagai genre berbondong-bondong ditayangkan, khususnya oleh Indosiar (remitivi.or.id, 2016).

Dari tahun 2014 hingga 2017 tren tayangan asing di televisi Indonesia mulai bergeser dan dipenuhi oleh drama Turki. Di ranah serial televisi, sinteron Indonesia perlahan mulai mengalah dengan kehadiran sinema drama Turki yang berhasil menyedot perhatian publik. Nielsen Television Audience Measurement melansir temuan yang menyebut bahwa drama Turki berhasil mengungguli sinteron dari sisi waktu menonton. Padahal, dari sisi jumlah serial, sinetron lokal memiliki 212 judul sepanjang tahun 2015, jauh tinggi dibandingkan drama Turki yang baru sebanyak 11 judul. Dilihat dari waktu tonton, rata-rata khalayak menonton serial Turki selama 31 menit per harinya, sedangkan serial India 21 menit, dan sinetron Indonesia hanya ditonton 18 menit per hari. Beberapa serial drama Turki yang mendapat atensi besar audiens Indonesia adalah Cansu \& Hazal (rating $3,2 \%)$, Shehrazat (2,7\%), Elif (2,6\%), dan Abad Kejayaan (2,1\%). Sedangkan sinetron lokal yang memiliki rating tinggi di tahun 2015 adalah Pangeran (4,4\%), Preman Pensiun 2 (4,3\%), Tukang Bubur Naik Haji The Series (3,9\%), dan $7 \quad$ Manusia Harimau sebesar 3,9\% (marketeers.com, 2015).

Menengok peta invasi tayangan asing di layar kaca Indonesia, rupanya kualitas tayangan lokal Indonesia - khususnya drama hiburan yang oleh pemerintah berupaya didorong untuk tampil dominan di televisi Indonesia dengan memunculkan aspek multikultural, mau tidak mau harus berhadapan dengan konten asing yang bernuansa baru. Ini menjadi tantangan serius bagi pemerintah dalam menerapkan kebijakan perlindungan terhadap tayangan berkonten multikultural Indonesia melalui Undang-undang Penyiaran, sekaligus tantangan bagi produsen tayangan lokal agar dapat meningkatkan kualitas kontennya guna memenangkan hati pemirsa televisi Indonesia tanpa merendahkan etnis tertentu. Bila pemerintah Indonesia tidak membatasi penayangan konten asing, maka bahaya laten yang akan muncul akibat paparan tayangan berbudaya asing adalah 
terkikisnya budaya lokal Indonesia. Hal ini sejalan dengan gagasan Cultural Imperialism Theory yang menganggap bahwa invasi budaya asing baik yang dikemas dalam bentuk tayangan televisi, apabila dikonsumsi khalayak secara terusmenerus maka akan dapat mempengaruhi budaya setempat.

\section{Implementasi Kebijakan Komunikasi Multikultural di Televisi Indonesia dalam Pusaran Imperialisme Budaya}

Hadirnya tayangan berbudaya asing membawa dampak bagi konten lokal. Meskipun pemerintah telah berupaya mengatur dalam UU Penyiaran bahwa isi siaran harus memajukan kebudayaan nasional. Selain itu, Pedoman Perilaku Penyiaran (P3-SPS) yang dikeluarkan KPI secara eksplisit mengatur batasan maksimal program siaran asing sejumlah $10 \%$ dari total waktu siaran per hari. KPI juga telah mengeluarkan surat teguran kepada ANTV karena menampilkan siaran asing melebihi $40 \%$ per hari. Namun dalam implementasinya, pemerintah masih dihadapkan dengan beragam permasalahan konten tayangan lokal, maupun pelanggaran kuota tayang.

Bentuk pelanggaran konten dapat ditelusuri dari beberapa contoh tayangan lokal yang tidak sesuai kadiah UU Penyiaran. Tayangan reality show "Ethnic Runaway" yang pernah tayang di Trans TV merupakan tayangan yang menampilkan selebritis untuk mengenal aktivitas dan kebiasaan sehari-hari dari suku tertentu di Indonesia. Mereka akan tinggal dan beradaptasi selama beberapa hari di lingkungan suku tertentu. Mereka harus mengikuti adat atau tradisi yang biasa dilakukan oleh suku daerah yang didatangi. Sering kali, tayangan ini mengkonstruksi adegan-adegan yang menampilkan kesalahpahaman antara para selebriti dengan warga setempat, yang diakibatkan oleh perbedaan sikap, perilaku, dan kebiasaan. Para selebriti yang memang berasal dari kota besar ditampilkan akan mengalami kejutan budaya (Aditama \& Kusuma, 2015).

Kejutan budaya merupakan keadaan mental yang datang dari transisi yang terjadi ketika seseorang pergi dari lingkungan yang dikenalnya ke lingkungan yang tidak ia kenal dan menemukan bahwa pola perilakunya yang dulu tidak efektif. Terdapat empat tahapan kejutan budaya atau yang lebih dikenal dengan istilah kurva-U, yaitu fase kegembiraan, fase kekecewaan, fase awal resolusi, dan fase berfungsi dengan efektif (Ryan \& Twibell dalam Samovar et al, 2010). Maksud dari tayangan Ethnic Runaway adalah baik yaitu mengenalkan kehidupan suku-suku Indonesia, tetapi yang kemudian dianggap menyalahi konten adalah setting berlebihan yang menampilkan kesalahpahaman komunikasi antara artis dengan suku lokal dan misi multikulturalnya menjadi kurang mengena. Disamping itu, sebelum berubah nama menjadi Ethnic Runaway, tayangan ini awalnya berjudul Primitive Runaway yang menuai kecaman penggunaan kata primitive yang kurang tepat. Primitif adalah label yang menyakitkan bagi masyarakat adat yang berasosiasi biadab, bodoh, terbelakang, dan belum manusia (Novita, 2012). Akhirnya nama tayangan ini diubah menjadi Ethnic Runaway dan Trans TV meminta maaf kepada publik (remotivi.or.id, 2011). Dengan demikian, akomodasi yang seharusnya menjadi kunci dalam multikulturalisme (Pawito, 2008) belum dapat diimplementasikan dengan baik dalam tayangan televisi Indonesia. 
Pelanggaran konten multkulturalisme dalam pemberitaan faktual di Indonesia juga masih ada. Contohnya hasil penelitian Mubarok (2012) menunjukkan bahwa pemberitaan terorisme di Indonesia lebih jauh lagi bahkan telah distigmatisasi oleh media besar sekelas Kompas. Kompas bahkan banyak mengaitkan pemberitaan mengenai terorisme dengan ideologi agama Islam dan ekspose terhadap anggota keluarga tersangka teroris dimana hal ini tidak mendidik masyarakat untuk bersikap tegas dalam menghadapi terorisme, namun justru memperuncing dikotomi kebencian masyarakat pada agama, suku, dan ideologi tertentu di Indonesia. Ini yang seharusnya menjadi bahan evaluasi bersama bagi lembaga penyiaran yang ada di Indonesia. Meskipun Kompas TV juga pernah menampilkan wawancara eksklusif dengan bintang tamu para mantan teroris di acara Rosi yang bertujuan berbagi pengalaman melepaskan diri dari jaringan teroris dan mewaspadai cara kerja jaringan tersebut, namun stasiun televisi masih perlu bersikap obyektif dalam memberitakan isu terkait SARA dan unsur budaya lainnya.

Bentuk pelanggaran konten multikulturalisme juga dapat ditemukan dalam tayangan drama lokal Indonesia. Misalnya dalam drama komedi, masih banyak ditemukan kekurangpatutan dalam merepresentasikan karakter tokoh yang berasal dari suku tertentu, yang akhirnya membentuk stereotype negatif. Sebagai contoh, dalam tayangan Keluarga Minus (Trans TV) dimana tante Minus (Minang) digambarkan sebagai sosok yang pelit dan serakah, Paijo (Jawa) memainkan karakter yang materialis dan mementingkan uang, Minus (Papua) diidentifikasikan sebagai orang yang lugu dan bodoh. Keluarga Minus telah mengembangkan "konstruksi stereotip", narasi berdasarkan prasangka etnis (Remotivi, 2011). Menurut Burton (2007), komedi dalam televisi ingin mengeksploitasi stereotip untuk membuat lucu karakter. Demikian halnya dengan drama komedi Suami-Suami Takut Istri dengan tokoh dari suku Minang, Jawa, Batak memunculkan stereotype orang Jawa yang lamban dan orang Batak berkarakter keras. Dari contoh tersebut menunjukkan bahwa multikulturalisme di layar kaca masih menjadi wilayah "seksi" di media dan justru menjadi "kebablasan" karena menimbulkan stereotype terhadap etnis tertentu dan menampilkan sekat-sekat yang jelas dalam masyarakat Indonesia yang multikultur (Sukmono \& Junaedi, 2014).

Selain pelanggaran konten, hal lain yang dikaji dalam pembahasan tulisan ini adalah terkait pelanggaran jam tayang oleh stasiun televisi Indonesia. Kasus pelanggaran jam tayang yang terjadi di televisi Indonesia umumnya disebabkan oleh porsi penayangan konten berbudaya asing yang melebihi kuota, serta penayangan konten lokal yang cenderung terpinggirkan. Invasi masuknya tayangan asing di layar kaca Indonesia memang tidak dapat dihindari. Globlalisasi telah menjadi produk dunia. Invasi tayangan berbudaya asing di televisi Indonesia adalah bukti bahwa Indonesia sedang menghadapi hegemoni budaya seperti yang menjadi gagasan utama Cultural Imperialism Theory.

Bahkan konteks budaya asing yang masuk bukan hanya kategori budaya Barat saja, termasuk budaya dari kawasan Asia lainnya seperti Bollywood (India), Korea, Jepang, China, Malaysia, Thailand. Mengapa tayangan impor sangat diminati di Indonesia dan sulit dicegah? Dalam hal 
ini, pemerintah dihadapkan pada kompleksitas implementasi UU Penyiaran. Bagi kepentingan konsumen, karakter penonton Indonesia cenderung bersikap shifting terhadap tayangan lokal maupun asing. Penonton memilih melihat tayangan asing karena mereka menginginkan suasana baru. Sedangkan penonton juga tetap berupaya mempertahankan tayangan lokal yang mereka sukai. Hal ini terjadi karena penonton merasakan adanya kedekatan budaya dengan tayangantayangan asing yang masuk, misalnya Turki dan Indonesia memiliki religi yang sama. Dalam prinsip Cultural Imperialism Theory, hegemoni imperialisme budaya dalam konteks ini telah bekerja di alam bawah sadar penonton televisi Indonesia yang mengakibatkan munculnya ketergantungan untuk menonton. Bagi kepentingan stasiun televisi, motif stasiun televisi memutar tayangan asing awalnya sebagai ajang uji coba untuk membangun rating, jika tayangan asing tersebut menjadi booming, maka stasiun televisi akan melanjutkan strategi tersebut. Selain itu, murahnya lisensi serial asing dibandingkan biaya produksi siaran lokal menjadi pertimbangan ekonomis bagi stasiun televisi (marketeers.com, 2015). Dengan kata lain, kebijakan multikultural yang termaktub dalam UU Penyiaran pada kenyataannya sedang berhadapan dengan kapitalisme dan kepentingan publik yang terhegemoni imperialisme kebudayaan asing.

Tidak mengherankan bila dalam prakteknya banyak stasiun televisi yang memilih nekat melanggar ketentuan UU Penyiaran terkait penayangan konten asing demi mendapatkan rating penonton. Format cerita bersambung dengan jumlah episode yang panjang adalah kekuatan utama drama asing berseri yang memungkinkan televisi dapat menjaring penonton tetap untuk slot siaran yang cukup lama, dan akan membuka peluang bagi pengiklan (Biltereyst \& Meers, 2000). Menanggapi permainan semacam ini, KPI berupaya menjatuhkan sanksi kepada stasiun televisi yang melakukan pelanggaran. KPI pernah menegur ANTV karena menampilkan siaran asing lebih dari $40 \%$ per hari dengan jam tayang lebih dari 10 jam (remotivi.or.id, 2016). Apabila tayangan berbudaya asing menjadi komoditi yang menjanjikan di stasiun televisi Indonesia, lantas bagaimana nasib tayangan lokal Indonesia? Tayangan konten lokal mau tidak mau harus bersaing kualitas dengan tayangan asing yang mulai diminati masyarakat Indonesia. Stasiun televisi melihat celah ini untuk memanipulasi aturan UU Penyiaran, yang mana konten lokal dengan rating rendah akan ditayangkan di jam "hantu" antara jam 00.00 sampai dengan 05.00 untuk memenuhi kuota penayangan konten lokal sebanyak $60 \%$ per hari. Guna menertibkan kenakalan stasiun televisi semacam ini, KPI masih perlu bekerja keras, konsisten, dan lebih tegas dalam menjatuhkan sanksi sesuai ketentuan.

\section{PENUTUP}

\section{Kesimpulan}

Komunikasi multikultural yang mewujud dalam bentuk tayangan televisi hasil produksi domestik Indonesia saat ini tengah menghadapi invasi tayangan berbudaya asing yang secara legal diizinkan tayang di televisi Indonesia. Hal ini memunculkan kompleksitas pada aspek implementasi UU Penyiaran di Indonesia 
dan kualitas konten dalam tayangan televisi Indonesia. Pertama, meskipun pemerintah telah menerbitkan kebijakan formal yang mengatur produksi konten yang berkualitas dan menjunjung tinggi aspek multikultural pada tayangan televisi yang dihasilkan, namun faktanya masih banyak kecurangan yang dilakukan stasiun televisi Indonesia terkait penayangan konten yang mengandung aspek multikulturalisme baik tayangan lokal maupun asing. Hal ini menunjukkan bahwa kebijakan pemerintah Indonesia melalui UU Penyiaran belum diimplementasikan secara maksimal. Kedua, rendahnya kualitas konten tayangan televisi Indonesia khususnya infotainment, sinetron, film televisi berdasarkan hasil evaluasi KPI menunjukkan masih adanya konten yang merendahkan pihak-pihak tertentu melalui karakter yang dimunculkan dalam tayangan. Hal ini bertentangan dengan prinsip UU Penyiaran. Ketiga, tayangan televisi hasil produksi domestik pada akhirnya harus bersaing dengan konten berbudaya asing yang sama-sama diizinkan tayang di televisi Indonesia.

Kemunculan tayangan berbudaya asing tersebut adalah bentuk nyata imperialisme budaya yang pada akhirnya dapat menimbulkan dampak seperti yang digagas oleh Cultural Imperialism Theory bahwa media massa akan dapat mengubah pola yang sudah ada dalam kelompok masyarakat tertentu. Lebih jauh, akan ada efek imitasi yang akan dilakukan oleh masyarakat. Sementara Pemerintah sendiri masih memiliki keterbatasan sumber daya dalam melakukan pengawasan menyeluruh atas tayangan di televisi Indonesia.

\section{Saran}

Pemerintah dan masyarakat perlu bekerjasama dalam upaya mengawasi dan mengkontrol konten tayangan multikultural baik baik hasil produksi domestik maupuan tayangan berbudaya asing. Hal ini sebagai upaya membangun kepercayaan kepada publik sekaligus sebagai kanal membentuk masyarakat yang kritis. Solusi tersebut diharapkan dapat menjawab keterbatasan pemerintah dalam melakukan kontrol tayangan multikultural khususnya di tayangan televisi Indonesia.

\section{DAFTAR PUSTAKA}

Ardianto, E. (2007). Komunikasi Massa Suatu Pengantar. Bandung: Simbosa Rekatama Media.

Burton, Graeme. (2007). Membincangkan Televisi: sebuah pengantar kepada kajian televisi. Terjemahan Oleh Rehmawati, Laila. Yogyakarta \& Bandung: Jalasutra.

Kriyantono, R. (2012). Etika \& Filsafat Ilmu Komunikasi. Malang: UB Press.

Littlejohn, S. W. (2005). Theories of Human Communication, 8th Edition. Belmont CA: Thomson Wadsworth.

Nurudin. (2007). Pengantar Komunikasi

Massa. Jakarta: PT. Rajagrafindo Persada.

Pawito. (2008). Media Massa dalam Masyarakat Pluralis. Jurnal Ilmu Komunikasi, Vol. 6, No. 2, MeiAgustus.

Purwasito, A. (2015). Komunikasi Multikultural. Yogyakarta: Pustaka Pelajar.

Samovar, L. A., Porter, R. E., \& McDaniel, E. R. (2010). Komunikasi Lintas Budaya: Communication Between Cultures. Jakarta: Salemba 
Humanika.

Sen, K., \& Hill, D. T. (2001). Media, Culture, and Politics in Indonesia. Melbourne: Oxford University Press.

Suknomo, F. G., \& Junaedi, F. (2014). Komunikasi Multikultur Melihat Multikulturalisme dalam Genggaman Media. Yogyakarta: Buku Litera.

Sutanto, M. H. et al. (2010). Diskursus Peran teori Komunikasi Massa Dalam Masyarakat. Yogyakarta: Litera.

\section{Sumber Lain}

Aditama, T. M. \& Kusuma, A. (2015). Media dan Keragaman Budaya Pendidikan Multikultural Pada Tayangan Televisi di Indonesia. Prosiding 9th International Conference on Malaysia-Indonesia Relations (PAHMI 9) 2015 "Harmony In Diversity: Building ASEAN Community 2015”. Yogyakarta: Universitas Negeri Yogyakarta.

Badan Pusat Statistik. (2017). [Online]. Tersedia dalam < https://www.bps.go.id/> diakses pada 26 November 2017.

Biltereyst, D., \& Meers, P. (2000). The International Telenovela Debate and the Contra-Flow Argument: A Reappraisal. Media, Culture \& Society 22, no. 4, p. 393-413.

Dunch, R. (2002). Beyond Cultural Imperialism: Cultural Theory, Christian Missions, and Global Modernity. History and Theory. Vol. 41, No. 3 (Oct, 2002), pp. 301-325.

Katadata.co.id. (2017). Penetrasi Televisi Masih yang Tertinggi. [Online]. Tersedia dalam $<$ https://databoks.katadata.co.id/datapub lish/2017/07/27/penetrasi-televisi- masih-yang-tertinggi> diakses pada 1 Desember 2017.

Kompas.com. (2016). Survei Litbang Kompas: Televisi Dua Sisi Mata Uang. [Online]. Tersedia dalam <http://nasional.kompas.com/read/2016/ 03/30/05374961/Survei.Litbang.Kompa s.Televisi.Dua.Sisi.Mata.Uang> diakses pada 2 Desember 2017.

Kpi.gi.id. (2016). Survei Indeks Kualitas Program Siaran dan Infotainment Harus Dibenahi. [Onlie]. Tersedia dalam

<http://www.kpi.go.id/index.php/id/liha t-terkini/38-dalam-negeri/33502survey-indeks-kualitas-program-siarantelevisi-sinetron-dan-infotainmentharus-dibenahi> diakses pada 9 Desember 2017.

Marketeers.com. (2015). Serial Drama Turki Ungguli Sinetron Indonesia. [Online]. Tersedia dalam < http://marketeers.com/serial-dramaturki-ungguli-sinetron-indonesia/> diakses pada 10 Desember 2017.

Mubarok. (2012). Stigmatisasi Pemberitaan Terorisme di Media Massa. Jurnal Interaksi. Vol 1 No 1.

Novita, R. (2012). Representasi Etnis dalam Program Televisi Bertema Komunikasi Antarbudaya. Tesis. Jakarta: Universitas Indonesia.

Rappler.com. (2017). Daftar Pemenang Indonesian Television Awards 2017. [Online]. Tersedia dalam $<$ https://www.rappler.com/indonesia/ga ya-hidup/182840-daftar-pemenangindonesian-television-awards-2017> diakses pada 29 November 2017.

Rinawati, R. (2002). Pengaruh Sinetron Terhadap Sikap Ibu-Ibu Mengenai Peran Ganda Wanita. MediatorJurnal Komunikasi, Volume 3. No. 1, hal.110. Remotivi.or.id. (2011). Ethnic Runaway 
Mencintai Indonesia dengan Jijik 1. [Online]. Tersedia dalam $<$ http://remotivi.or.id/amatan/ethnicrunaway-mencintai-indonesia- denganjijik-1> diakses pada 14 November 2017.

Remotivi.or.id. (2016). Di Balik Tren Tayangan Impor. [Online]. Tersedia dalam $<$ http://www.remotivi.or.id/amatan/311/ Di-Balik-Tren-Tayangan-Impor > diakses pada 10 Desember 2017 